\title{
Retinal Vasoconstriction in Premature Infants with Increased Arterial Oxygen Tensions
}

\author{
J. D. BAUM and C. J. BULPITT \\ From the Neonatal Research Unit, Institute of Child Health, Hammersmith Hospital, and \\ The Department of Medicine, Royal Postgraduate Medical School, Hammersmith Hospital, London
}

Baum, J. D., and Bulpitt, C. J. (1970). Archives of Disease in Childhood, 45, 350. Retinal vasoconstriction in premature infants with increased arterial oxygen tensions. Retinal vessels of newborn and premature infants were photographed under conditions of increasing arterial oxygen tension and the changes in vessel diameter were measured.

In 6 infants studied, there was a consistent pattern of vasoconstriction with rise in $\mathrm{P}_{\mathrm{a}} \mathrm{O}_{2}$.

The reduction in calibre could be measured, but was not detectable by viewing the retina, unless photographs taken at low and high $\mathrm{P}_{\mathrm{a}} \mathrm{O}_{2}$ were viewed side by side. Frank retinal vasospasm did not occur even at a $\mathrm{P}_{\mathrm{a}} \mathrm{O}_{2}$ of $250 \mathrm{~mm}$. $\mathrm{Hg}$.

It was concluded that ophthalmoscopy did not provide an alternative to direct frequent measurement of $\mathrm{P}_{\mathrm{a}} \mathrm{O}_{2}$ in premature infants receiving oxygen therapy.

In 1927, Tinel first showed that an increase in inspired oxygen concentration produced constriction of the cerebral vasculature. This observation has subsequently been confirmed.

Similar changes in retinal blood vessels were described in 1940 by Cusick, Benson, and Boothby, which have been shown to relate to changes in arterial oxygen tension by Frayser et al. (1967).

Oxygen was suspected as the major factor in the pathogenesis of retrolental fibroplasia early in the 1950s (Campbell, 1951; Crosse and Evans, 1952; Patz, Hoeck, and De La Cruz, 1952). It was subsequently conclusively shown in newborn animals that oxygen was the primary toxic factor involved (Ashton, Ward, and Serpell, 1953; Patz, 1954; Gyllensten and Hellström, 1954). More recently, Ashton and Pedler (1962) have published further experimental studies showing that prolonged hyperoxaemia has a selective damaging effect on developing endothelial cells leading to their degeneration with irreversible obliteration of the developing retinal capillaries. It is this fundamental change that leads to the chain of events of local retinal ischaemia, new vessel formation, haemorrhage, retinal detachment, and scarring. The fear of inducing blindness has resulted in the present dilemma as to the proper place of oxygen

Received 11 September 1969. in the treatment of the hypoxic newborn infant. It has recently been suggested by Patz (1967) that ophthalmoscopic monitoring of the retinal vessels in the newborn might be a satisfactory guide to arterial oxygen tensions in situations where direct measurement is not possible.

In the present study we measured the changes in retinal vessel diameter in newborn and premature infants that occur when the level of arterial oxygenation is altered between measured limits.

\section{Methods}

Retinal photographs were taken with a vertically mounted Zeiss Fundus camera (Bulpitt and Baum, 1969). Only certain infants were considered suitable for this investigation, as it was necessary that they should fulfil the following criteria. First, the retina should be clearly visible-this excludes infants of less than 32 weeks' gestation in whom the tunica vasculosa lentis is o still intact about the lens; secondly the infants should $N$ be well enough for photography which involves their removal from the incubator; thirdly their respiratory insufficiency should be such that, when breathing room air, a low $\mathrm{P}_{\mathrm{a}} \mathrm{O}_{2}$ is reached, while when breathing $100 \%$ oxygen the $\mathrm{P}_{\mathrm{a}} \mathrm{O}_{2}$ rises high enough to give a reasonable span of oxygenation.

The infants included in this study were babies on the neonatal ward who were recovering from respiratory distress. They were allowed to breathe room air for 15 minutes, while retinal photographs were taken. 


\section{Retinal Vasoconstriction in Premature Infants with Increased Arterial Oxygen Tensions 351}

This procedure was repeated with the infant breathing $100 \%$ oxygen by face mask.

The $\mathrm{P}_{\mathrm{a}} \mathrm{O}_{2}$ was measured on each occasion using the Instrumentation Laboratory Oxygen electrode. Four infants had indwelling arterial catheters for clinical $\mathrm{P}_{\mathrm{a}} \mathrm{O}_{2}$ monitoring, one in the umbilical artery and three in the right radial artery. In the other infants samples were taken of capillary blood from a heel which had been previously warmed in three cases and arterial blood from a radial artery stab in one case. Only one site was used for sampling in each case.

Retinal photographs were taken after the baby had been exposed to air or oxygen for 5 minutes. Further photographs were taken at approximately one-minute intervals over the following 10 minutes while still receiving air or oxygen. From the colour transparencies a composite drawing of the retinal vessels was made. Arterioles and venules suitable for measurement were chosen. These were required to be clearly in focus, identifiable from film to film by some landmark such as vessel bifurcation, and represented on at least two sets of films at different levels of $\mathrm{P}_{\mathrm{a}} \mathrm{O}_{2}$.

Measurement of vessel diameter was made using a microscope with a micrometer eye-piece. Each diameter measurement was the mean of at least four readings.

\section{Results}

We only report here the changes observed when the $\mathrm{P}_{\mathrm{a}} \mathrm{O}_{2}$ was raised by $50 \mathrm{~mm}$. $\mathrm{Hg}$ or more, as was the case in six of the infants studied ranging in gestational age from 32-38 weeks (Table I). One infant was 29 weeks of gestation by dates, but his physical appearance, neurological behaviour, and the absence of a tunica vasculosa lentis pointed to a gestation nearer 32-34 weeks. The birthweights of the infants ranged from $1390-3400 \mathrm{~g}$. One infant was West Indian; the other five were Caucasian. Four infants were studied in the first week of life, one on the 8th and one on the 50th day. The last patient had protracted respiratory insufficiency of uncertain origin. One infant was receiving assisted ventilation at the time of the study.

TABLE I

Particulars of the 6 Infants who were Studied

\begin{tabular}{c|c|c|c|c|c}
\hline $\begin{array}{c}\text { Case } \\
\text { No. }\end{array}$ & $\begin{array}{c}\text { Gestational } \\
\text { Age (wk.) }\end{array}$ & $\begin{array}{c}\text { Weight } \\
(\mathbf{g} .)\end{array}$ & Race & $\begin{array}{c}\text { Day of } \\
\text { Study }\end{array}$ & $\begin{array}{c}\text { On } \\
\text { IPPV }\end{array}$ \\
\hline 1 & $? 29$ & 1920 & Caucasian & 2 & - \\
2 & 32 & 1390 & Caucasian & 3 & - \\
3 & 32 & 1620 & Caucasian & 1 & - \\
4 & 32 & 2040 & West Indian & 5 & - \\
5 & 36 & 2580 & Caucasian & 8 & - \\
6 & 38 & 3400 & Caucasian & 50 & - \\
\hline
\end{tabular}

IPPV, intermittent positive pressure ventilation.
The range of $\mathrm{P}_{\mathrm{a}} \mathrm{O}_{2}$ differed from baby to baby (Table II). The lowest $\mathrm{P}_{\mathrm{a}} \mathrm{O}_{2}$ was $16 \mathrm{~mm}$. $\mathrm{Hg}$, and the highest $250 \mathrm{~mm}$. $\mathrm{Hg}$. All the infants studied showed vasoconstriction with increase in $\mathrm{P}_{\mathrm{a}} \mathrm{O}_{2}$.

TABLE II

Range of $\mathrm{P}_{\mathrm{a}} \mathrm{O}_{2}$ and Sampling Site in the 6 Infants Studied

\begin{tabular}{c|c|c}
\hline Case No. & Range $\mathrm{P}_{\mathrm{a}} \mathrm{O}_{2}$ & \multicolumn{1}{c}{ Sampling Site } \\
\hline 1 & $\left\{\begin{array}{r}27 \\
125 \\
55\end{array}\right.$ & Radial artery catheter \\
2 & $\left\{\begin{array}{r}40 \\
235\end{array}\right.$ & Umbilical artery catheter \\
3 & $\left\{\begin{array}{r}170 \\
41\end{array}\right.$ & Radial artery catheter \\
250 & $\left\{\begin{array}{r}35 \\
120\end{array}\right.$ & Arterialized capillary blood \\
4 & $\left\{\begin{array}{r}40 \\
200\end{array}\right.$ & Arterialized capillary blood \\
120 & Radial artery stab \\
6 &
\end{tabular}

The results of a typical case are shown in Fig. 1. In this case the $\mathrm{P}_{\mathrm{a}} \mathrm{O}_{2}$ was raised from 35 to $120 \mathrm{~mm}$. $\mathrm{Hg}$ and veins and arteries of all sizes showed a reduction in vessel diameter with rise in $\mathrm{P}_{\mathrm{a}} \mathrm{O}_{2}$.

In Fig. 2 percentage constriction is plotted against the rise in $\mathrm{P}_{\mathrm{a}} \mathrm{O}_{2}$ for all the vessels measured in the six infants. Percentage constriction was calculated using the mean vessel diameter rather than the original diameter as the denominator.

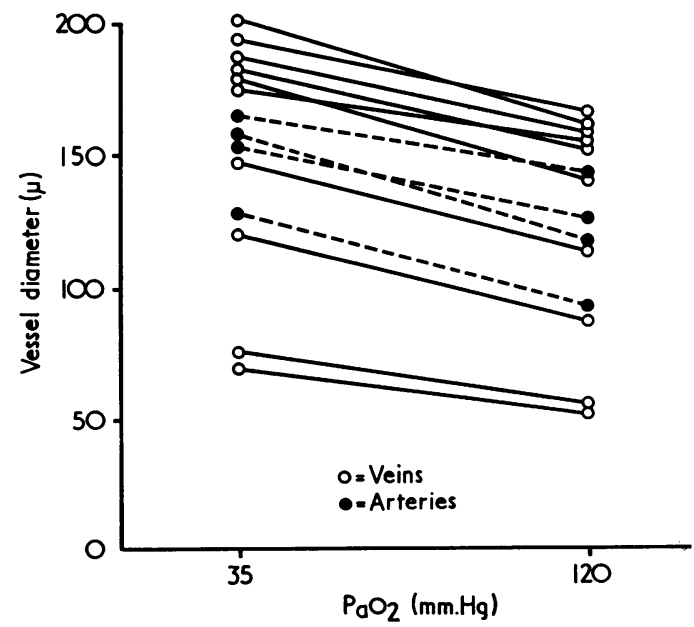

FIG. 1.-The results for Case 4 showing the reduction in vessel diameters when measured at a $\mathrm{P}_{\mathrm{a}} \mathrm{O}_{2}$ of 35 and 120 $\mathrm{mm} . \mathrm{Hg}$. 


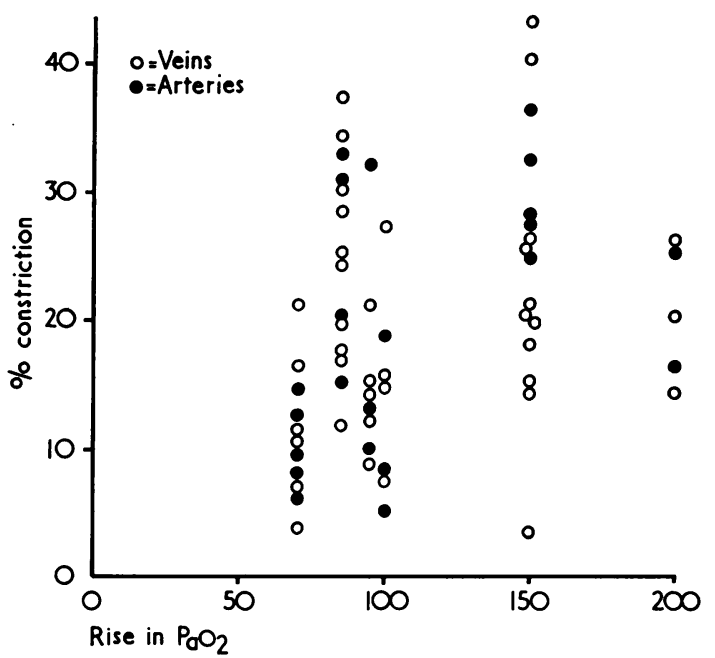

Fig. 2.-The percentage constriction for the vessels, measured in the 6 infants whose $P_{\mathrm{a}} \mathrm{O}_{2}$ was raised by more than $50 \mathrm{~mm}$. $\mathrm{Hg}$.

The greater the rise in $\mathrm{P}_{\mathrm{a}} \mathrm{O}_{2}$, the greater was the degree of vasoconstriction $(r=0.26, p=0.02)$.

As an index of vasoconstriction one can calculate the percentage change in vessel diameter for 100 $\mathrm{mm}$. $\mathrm{Hg}$ rise in $\mathrm{P}_{\mathrm{a}} \mathrm{O}_{2}$. For the six infants in this study the mean vasoconstriction index for the arteries is 18 , with a range of $5-39$, and for the veins 17 , with a range of $0-43$.

Though the pattern of constriction is represented $\overrightarrow{\vec{F}}$ in Fig. 1 as a straight line, we cannot be certain that $-{ }^{-}$ for a given vessel equal increments of rise in $\mathrm{P}_{\mathrm{a}} \mathrm{O}_{2}$ 응 produce equal increments of constriction over $\overline{\bar{c}}$ different parts of the $\mathrm{P}_{\mathrm{a}} \mathrm{O}_{2}$ range.

\section{Discussion}

During the epidemic of retrolental fibroplasia it. was noted that the earliest sign of the disease was $\vec{\omega}$ an extreme narrowing of the retinal vessels ( $\mathrm{La} \stackrel{\mathrm{N}}{\mathrm{N}}$ Motte and Tyner, 1950; Patz et al., 1952). ¿ Patz (1967) regarded such constriction as a sign of oxygen overdosage, and failure of the vessels to or reopen when the infant is taken out of oxygen as a pointer that the infant is likely to develop $\overrightarrow{\dot{\omega}}$ retrolental fibroplasia. He recommended ophthal- $/$ I moscopy as a means of monitoring oxygen therapy when facilities for direct $\mathrm{P}_{\mathrm{a}} \mathrm{O}_{2}$ measurement are not $\stackrel{\mathrm{C}}{\mathrm{C}}$ available.

Our observations confirm the findings of others working with adult subjects and animals that ${ }^{\oplus}$ raising the $\mathrm{P}_{\mathrm{a}} \mathrm{O}_{2}$ produces a constriction of the $\overrightarrow{0}$ retinal blood vessels of premature babies. Their 0 reduction in vessel diameter is measurable under the microscope and may even be detectable with the naked eye when films at low and high $\mathrm{P}_{\mathrm{a}} \mathrm{O}_{2}$ are mounted side by side (Fig. 3). In this study

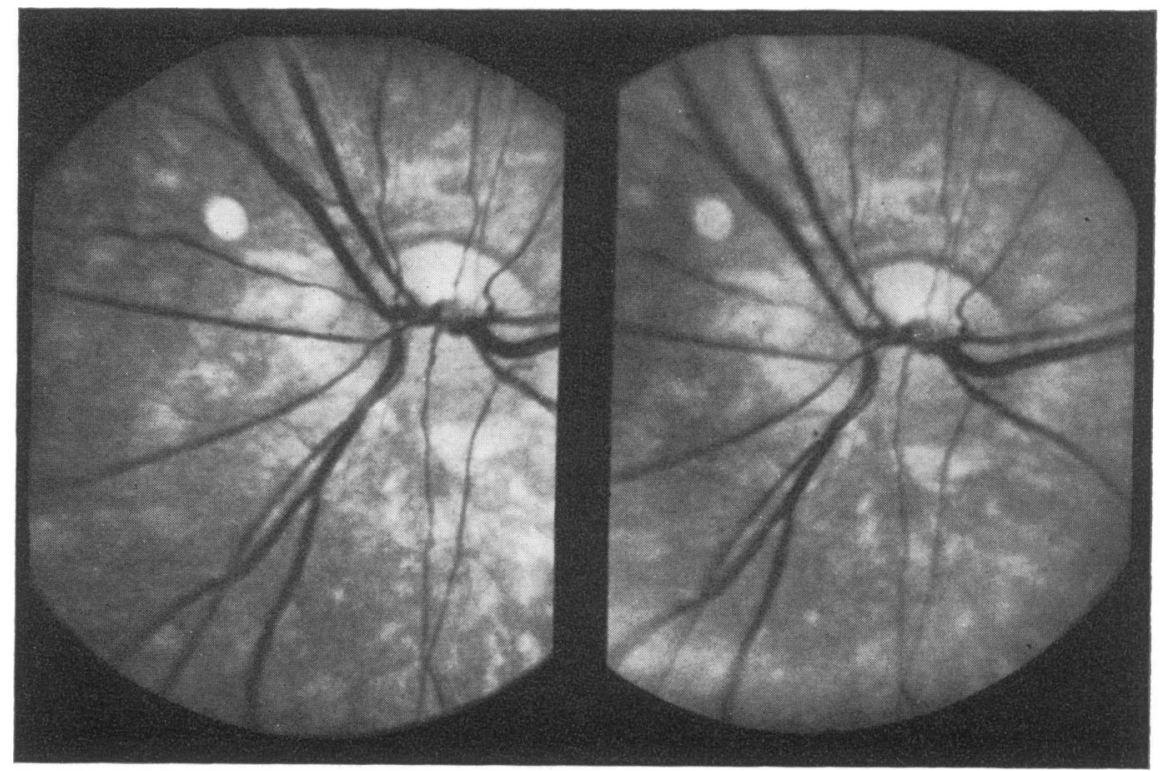

FIG. 3.-Retinal photographs from Case 4 showing the appearance of the vessels at a $\mathrm{P}_{\mathrm{a}} \mathrm{O}_{2}$ of $35 \mathrm{~mm}$. $\mathrm{Hg}$ at the left, and at a $\mathrm{P}_{\mathrm{u}} \mathrm{O}_{2}$ of $120 \mathrm{~mm} . \mathrm{Hg}$ on the right. 


\section{Retinal Vasoconstriction in Premature Infants with Increased Arterial Oxygen Tensions 353}

we neither saw nor photographed a retina which could be considered in isolation to show vasospasm, even at a $\mathrm{P}_{\mathrm{a}} \mathrm{O}_{2}$ of $250 \mathrm{~mm}$. $\mathrm{Hg}$. Since completing this study, we have seen an infant whose retinal vessels showed extreme vasoconstriction. This child was admitted from another hospital and had received oxygen for 2 weeks without $\mathrm{P}_{\mathrm{a}} \mathrm{O}_{2}$ measurement.

It seems likely that the duration of exposure, as well as the level of $\mathrm{P}_{\mathrm{a}} \mathrm{O}_{2}$, is important in determining the degree of vasoconstriction that occurs (Ashton, 1957). It may be that a $\mathrm{P}_{\mathrm{a}} \mathrm{O}_{2}$ of $250 \mathrm{~mm}$. $\mathrm{Hg}$ acting over many hours would produce recognizable retinal ischaemia. We did not feel justified in exceeding 15 minutes of exposure to high oxygen concentrations, but films taken at 5 and 15 minutes after raising the $\mathrm{P}_{\mathrm{a}} \mathrm{O}_{2}$ show no difference in the degree of vasoconstriction.

Our findings show that the absence of extreme vasospasm is not an indication that the $\mathrm{P}_{\mathrm{a}} \mathrm{O}_{2}$ is within safe limits (Roberton et al., 1968). Moreover, the majority of infants with respiratory distress are immature and still have a tunica vasculosa lentis. While it is usually possible to see the retinal vessels through this with an indirect ophthalmoscope, the view is never very clear and using the instrument requires considerable experience. Thus, while the finding of extreme vasospasm in the retina of a premature infant receiving oxygen therapy is a sign of oxygen overdosage and an urgent indication for a reduction in the inspired oxygen concentration, ophthalmoscopy is not an adequate method of monitoring arterial oxygenation. It is not a substitute for direct and frequent measurement of arterial oxygen tension in the management of a premature infant who is receiving oxygen therapy.

We wish to thank Professor C. T. Dollery and Professor J. P. M. Tizard for their advice and encouragement with this work; Sister Castle and her staff on the Neonatal Unit for their kind co-operation; and the Sir William Coxen Trust for laboratory facilities provided.
This work was supported by the Percy J. Neate Research Fellowship of the Clothworkers Company (J.D.B.) and grants from the Medical Research Council and Tobacco Research Council.

\section{REFERENCES}

Ashton, N. (1957). Experimental retrolental fibroplasia. Annual Review of Medicine, 8, 441.

IX. Reaction of endothelial cells to oxygen. British fournal of Ophthalmology, 46, 257.

- Ward, B., and Serpell, G. (1953). Role of oxygen in the genesis of retrolental fibroplasia. British fournal of Ophthalmology, 37, 513.

Bulpitt, C. J., and Baum, J. D. (1969). Retinal photography in the newborn. Archives of Disease in Childhood, 44, 499.

Campbell, K. (1951). Intensive oxygen therapy as a possible cause of retrolental fibroplasia. Medical fournal of Australia, $2,48$.

Crosse, V. M., and Evans, P. J. (1952). Prevention of retrolental fibroplasia. Archives of Ophthalmology, 48, 83.

Cusick, P. L., Benson, O. O., Jr., and Boothby, W. M. (1940). Effect of anoxia and of high concentrations of oxygen on the retinal vessels. Proceedings of the Staff Meetings of the Mayo Clinic, 15, 500.

Frayser, R., Saltzman, H. A., Anderson, B., Jr., Hickam, J. B., and Sieker, H. O. (1967). The effect of hyperbaric oxygenation on retinal circulation. Archives of Ophthalmology, 77, 265.

Gyllensten, L. J., and Hellström, B. E. (1954). Experimental approach to the pathogenesis of retrolental fibroplasia. I. Changes of the eye induced by exposure of newborn mice to concentrated oxygen. Acta Paediatrica, 43, Suppl. 100, 131.

La Motte, W. O., Jr., and Tyner, G. S. (1950). Observations on retrolental fibroplasia. Archives of Ophthalmology, 44, 620.

Patz, A. (1954). Clinical and experimental studies on the role of oxygen in retrolental fibroplasia. Transactions of the American Academy of Ophthalmology, 58, 45.

- (1967). New role of the ophthalmologist in prevention of retrolental fibroplasia. Archives of Ophthalmology, 78, 565.

- Hoeck, L. E., and De La Cruz, E. (1952). Studies on the effect of high oxygen administration in retrolental fibroplasia. I. Nursery observations. American fournal of Ophthalmology, $35,1248$.

Roberton, N. R. C., Gupta, J. M., Dahlenburg, G. W., and Tizard, J. P. M. (1968). Oxygen therapy in the newborn. Lancet, 1, 1323.

Tinel, J. (1927). Régulation de la circulation cérébrale à l'inhalation d'oxygène. Comptes Rendus des Séances de la Suciété de Biologie, 96, 665.

Correspondence to Dr. J. D. Baum, Department of Child Health, Hammersmith Hospital, Du Cane Road, London W.12. 